\title{
Nutrition and Behaviour: The Role of $\omega 3$ Fatty Acids
}

\author{
Agnieszka Wilczynska-Kwiatek ${ }^{1, *}$, Ram B. Singh $^{2}$ and Fabien De Meester ${ }^{3}$ \\ ${ }^{1}$ Institute of Psychology Katowice, TsimTsoum Institute Krakow, Poland \\ ${ }^{2}$ Department of Internal Medicine and Cardiology, Halberg Hospital and Research Institute, Civil Lines, Moradabad-10, \\ UP 244001, India; TsimTsoum Institute Krakow, Poland \\ ${ }^{3}$ Columbus Paradigm Institute, Waterloo, Belgium; TsimTsoum Institute Krakow, Poland
}

\begin{abstract}
This review article gathers evidence on the potential relationship between dietary intake of $\omega 3$ polyunsaturated fatty acids ( $\omega 3$ PUFAs) and mental function. Several pieces of evidence that $\omega 3$ PUFAs influence affective and cognitive function are presented.

Although published data and results available in the field remain limited and sometimes ambiguous, they have shed a new light on the role of proper diet in general, $\omega 3$ PUFAs in particular, in many mental disorders and dysfunctions, including depression and cognitive decline in aging. The analysis of the influence of fatty acids on human health allows us to formulate a new, more holistic approach to both prevention and treatment of psychological disorders and dysfunctions. What is more, it appears that 13 PUFAs have a beneficial influence on mental function in healthy people as well.

The currently available data concerning the influence of fatty acids on behaviour and mental function are still insufficient and suffer so far from lack of standard determination of background, intermediairy and endpoint omega-6/3 ratios in plasma lipids of patients involved in both epidemiological and intervention studies. There is a great need for further refined trials in the field.
\end{abstract}

Keywords: Diets, food, nutrients, nutraceuticals, depression, anxiety, type A behaviour.

\section{INTRODUCTION}

It is known that brain function is highly sensitive to dietary nutrients. One of the probably best known examples is caffeine, which is contained in tea, coffee, chocolate etc. Caffeine is a stimulant that improves mental alertness and performance. Many other dietary elements - from vitamins to macro-elements - influence brain biochemistry and function. Some silently while others have been reported to have behavioural and functional effects. As the study of brain nutrition and, in particular, its impact on brain function and behaviour is relatively new, it is not surprising that gaps remain to be filled in our knowledge of the biochemical, physiological, psychological and behavioural aspects of the effects of diet on brain function. However, accurate and relevant data are available from where functional effects appear obvious though underlying mechanisms are still poorly understood. The aim of this article is to review and discuss the effects of essential nutrients (particularly $\omega 3$ PUFAs) on psychological function and mental health.

\section{NUTRIENTS AND BRAIN FUNCTION}

Polyunsaturated fatty acids (PUFAs) constitute key structural components of phospholipid membranes in body tissues. They are highly concentrated in the central nervous

*Address correspondence to this author at the University of Silesia, Institute of Psychology, ul. Grażyńskiego 53, 40-126 Katowice, Poland; E-mails: agnieszka.wilczynska-kwiatek@us.edu.pl or agnieszkawk@hotmail.com system (CNS) and human brain [1]. They play a role in nervous system activity, neuroplasticity of nerve membranes [2], synaptogenesis [3], synaptic transmission [4] and neurotransmitter uptake. Most neurotransmitters, i.e. catecholamines, acetylcholines and serotonin, also affect the function of the cardiovascular system, in addition to their effects on neuropsychiatric dysfunctions [5-8]. The synthesis of neurotransmitters has been shown to also depend on a number of other essential nutrients such as tryptophan, tyrosine, arginine. and choline [6,7]. There is evidence that $\omega 3$ fatty acids and other nutrients can affect cognitive function, mood, type-A behaviour, and depression [6-14]. In this respect,

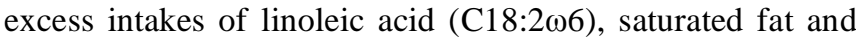
trans-unsaturated fats, refined carbohydrates, are proinflammatory leading to increased plasma levels of activating protein-1 (AP-1) and early response growth protein-1 (ERGP-1), which are transcription factors for proinflammatory cytokines. These latter cytokines appear to be positively associated with depression and type-A behaviour which are also risk factors for heart disease. On the other hand, $\omega 3$ fatty acids, monounsaturated fatty acids, antioxidant vitamins, flavonoids, coenzyme Q10, potassium, magnesium, calcium and moderate alcohol seem to have beneficial effects on brain and heart function as well as on mental function (Table 1).

The brain is responsible for approximately one fifth of the basal metabolism, which is fuelled by glucose and oxygen. Protein and lipids material are essential to the growth 
and regeneration of myelin sheaths and axis cylinders as well as for enzyme systems needed for cellular metabolism and neuroprotection. Vitamins, minerals and electrolytes, $\omega 3$ fatty acids and coenzyme Q10 in the neurons may influence the excitability of nerve centres. These vitamins, minerals, antioxidants, flavonoids and $\omega 3$ fatty acids should be adequately available as these nutrients can affect glucose metabolism, which is necessary for neuronal functions. Deficiencies in B vitamins, including folic acid, may be connected with psychological disorders. Epidemiological studies indicate that consumption of diets rich in antioxidants and anti-inflammatory compounds such as those found in fruits and vegetables (i.e. polyphenols), may lower the risk of developing age-related, neurodegenerative diseases, such as Alzheimer's or Parkinsons's diseases [15].

Table 1. Nutrients Having Possible Effects on Brain and Psychological Function

\begin{tabular}{|l|l|}
\hline Beneficial Effects & Adverse Effects \\
\hline \hline Omega 3 fatty acids & Excess of Total fat \\
Monounsaturated fatty acids & Excess of Saturated fat \\
Vegetable proteins & Trans fat \\
Soluble fiber & Excess of Linoleic acid \\
Vitamins; A,E,C, beta-carotines & Excess of Sodium \\
B vitamins and folic acid & \\
Coenzyme Q10 & \\
Flavonoids & \\
Potassium & \\
Magnesium & \\
Calcium & \\
Zinc & \\
Copper & \\
Selenium & \\
Chromium & \\
\hline
\end{tabular}

\section{POLYUNSATURATED FATTY ACIDS (PUFAS)}

Omega-6/3 PUFAs are essential to mammals, including humans; they cannot be synthesized in vivo and have to be obtained from the diet. PUFAs are composed of a hydrocarbon chain of variable lengths with a methyl group at one end (omega end), a carboxyl group at the opposite end, and several double bonds in between. The position of the first double bond differentiates $\omega 3$ fatty acids (i.e. C18:3 $\omega 3$ or ALA or alpha-linolenic acid) and $\omega 6$ fatty acids (i.e. C18:2 $\omega 6$ or LA or linoleic acid) [10]. $\omega 3$ PUFAs have their first double bond at the third carbon, while $\omega 6$ PUFAs at the sixth carbon from the omega end. In the wild, ALA, often referred to as short chain $\omega 3$ PUFA, can be metabolized to longer chain $\omega 3$ PUFA, mainly eicosapentaenoic acid (EPA, C20:5 03 ) and docosahexaenoic acid (DHA, C22:6 13 ), whereas LA can be

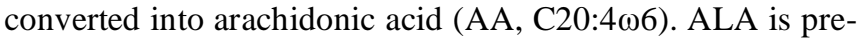
sent in greens, chia, flax, perilla, mustard seeds and oils, walnuts, soy beans, wheat; EPA and DHA are typically present in wild meat and eggs, and fish (salmon, tuna, herring etc.); LA is present in maize, sunflower, soy bean and sesame oil; ARA is typically present is modern meat and eggs.

Biochemical data show that $\omega 3$ PUFAs play an important role in neural structure and function. The brain and CNS contain high concentrations of $\omega 3$ PUFAs and several studies suggest a role for $\omega 3$ PUFAs in neurotransmitter synthesis, degradation, release, reuptake and binding [16-18]. Fatty acids and phospholipids are part of all biological membranes. The membrane's fluidity, of crucial importance for its functioning, depends on its lipid components; PUFAs increase membrane fluidity according to their number of double bonds, whereas free cholesterol (CHL) increases membrane viscosity so that the end result depends on the PUFAs/CHL desaturation index [19]. DHA deficit is associated with dysfunctions of neuronal membrane stability and transmission of serotonin, norepinephrine and dopamine, which might be related to the aetiology of mood and cognitive dysfunction and depression. On the other hand, EPA is essential to balancing the immune function and physical health by reducing the proportion of arachidonic acid (AA,

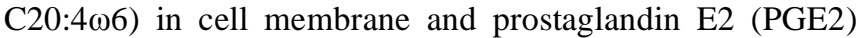
synthesis. A diet based on a high proportion of PUFAs allows for a higher incorporation of cholesterol in cell membranes to balance their fluidity, which, in turn, appear to contribute to lower blood cholesterol levels.

The types of fatty acids available for the make-up of cell membranes depend upon their relative presence in the diet. The retina and brain, in particularly the cerebral cortex, are rich in $\omega 3$ PUFAs [3,20], and the role of $\omega 3$ in visual and cognitive development has been described [21-24]. Any dietary deficiency in $\omega 3$ PUFAs has consequences for cerebral development, modifying the activity of enzymes imbedded in cerebral membranes. In addition, it has been reported that maternal intake of $\omega 3$ PUFAs during pregnancy and lactation may have a favourable effect on the later mental development of children [24, 25].

The critical factor in fatty acids' efficacy does not seem to be their absolute dietary intakes, but rather the ratio between their various types $(\mathrm{C} 18,20,22-\omega 6 / 3)$. It is known that the relative amounts of $\omega 6$ and $\omega 3$ PUFAs in cell membranes guide their function [26,27]. PUFAs are precursors of prostaglandins and leukotrienes, which are involved in inflammation and immune response. A diet rich in fish oil ( $\omega 3$ PUFAs) reduces production of inflammatory cytokines PGE2, helps in the treatment of chronic inflammatory diseases such as rheumatoid arthritis and prevents the onset of hormone-dependent tumours (i.e. prostatic cancer) by antagonizing the formation of cancerogenic factors [28].

In conclusion, $\omega 3$ PUFAs play a crucial role in numerous cellular functions, including membrane fluidity, membrane enzyme activities and eicosanoid synthesis; in such respect they are essential for brain development in infants and also required for maintaining normal brain function [29]. Early reports suggested that large amounts of $\omega 3$ PUFAs could cause prolonged bleeding times, possibly resulting in hemorrhagic stroke, and oxidative damage to various tissues [30]. For this reason it is often suggested to accompany $\omega 3$ PUFAs supplementation with various antioxidants such as vitamins $\mathrm{E}, \mathrm{A}$ and $\mathrm{C}$, flavonoids, polyphenols etc. In fact, 
many pieces of evidence indicate that antioxidants are also essential for maintaining a healthy neurophysiology.

\section{NUTRIENTS AND AFFECTIVE FUNCTION}

Omega-3 long chain polyunsaturated fatty acids appear beneficial in the treatment of several human conditions and diseases, including depression, schizophrenia and dementia [i.e. 40, 85]. Omega-3 treatment of these diseases often shows positive effects [31-35]. Discussion of its effects on depression, although it might be considered controversial, has led to the conclusion that $\omega 3$ PUFAs can affect both affective and cognitive function, and may even act as a "mood stabilizer" [34].

Over the last decades since the 1940s, the age of onset of major depression in the western world has declined, and its incidence, on the whole, has increased up to twenty-fold [41]. According to the World Health Organisation, depression is one of the most important diseases in the world, a fact reflected in the huge increase in the prescription of antidepressive drugs in the western world, now about three times as many as just two decades ago. Clinical manifestations of depression are fatigue, loss of vigour, anger, hostility, confusion, and anxiety. WHO data indicate that the prevalence of depression in modern societies is relatively high - about 5$10 \%$. Among the ten most important disorders in developed countries ranked according to the "years lived with disability" index (YLD), major depressive disorder termed 'unipolar major depression', clearly turned out to be ahead of all others. In addition, 'bipolar disorder', a condition in which periods of depression alternate with periods of mania, ranks sixth on the list. To put that into perspective, diabetes was tenth. In terms of "years lost due to premature death" (YLPD), 'unipolar major depression' ranked second only to cardiovascular diseases (CVD). In a further analysis, WHO predicted a clear-cut increase in the relative prominence of depression over the next 20 years. Depression is the most frequent psychiatric disorder and it affects well-being in a more fundamental way than other disorders. It is a life-threatening disorder, as about $15 \%$ of people with severe depression commit suicide.

Several lines of evidence suggest that there is a relation in humans between dietary intake of $\omega 3$ PUFAs and depressed mood. There is epidemiologic evidence that $\omega 3 \mathrm{PU}-$ FAs play a role in affective function. Numerous studies have shown a clear link between the drop in $\omega 3$ PUFAs consumption (i.e. fish) and the risk of depression, particularly as the incidence of this disorder varies, depending on the country, parallel with fish consumption. In this regard, numerous negative correlations have been demonstrated between worldwide fish consumption and rates of depression. One of the most famous and the most spectacular studies in this area was conducted by Joseph R. Hibbeln [36]. They showed a strong negative association $(\mathrm{r}=-0,84)$ between fish intake and depression across 13 countries (among 35000 citizens). Silvers and Scott [35] found that the personal perception of good mental and physical health varies with the consumption of fish (rich in $\omega 3$ PUFAs) in New Zealand. Timonen et al. [37] showed an increased risk of developing depression in persons who rarely ate fish compared with regular fish eaters. Other analysis [38] reported a connection between dietary seafood intake and protection against bipolar disorder and against seasonal affective disorder [39]. Similar results have been reported by Parker et al. [40].

Here, it is worthwhile to emphasize that the studies cited above are cross-sectional and that significant correlations may always reflect associations with other uncontrolled factors (i.e. smoking).

A relationship between $\omega 3$ intake and depressed mood has also been found in clinical studies. However, only a few studies have focused on dietary factors, a fact which shows their underestimated recognition in research on depression. Lower concentrations of $\omega 3$ have been reported in the plasma/red blood cell membranes of persons with major depressive disorder diagnosis compared with matched non-depressed control subjects [41-43]. Tiemeier et al. [44] found in a group of 567 participants statistically significant lower $\omega 3$ PUFAs levels, and higher $\omega 6 / \omega 3$ ratios in blood serum in individuals with depressive disorder than in the non-depressed control group. Stoll et al. [34] observed improvements in the depressive symptoms associated with bipolar disorder after supplementation with $\omega 3$ PUFAs compared with placebo, and Nemets et al. [45] reported benefits of $\omega 3$ PUFAs compared with placebo for treating unipolar disorder.

The role of $\omega 3$ PUFAs in major depressive disorder has been studied by Su et al. [69]. They conducted an 8-week double-blind, placebo controlled trial comparing $\omega 3$ PUFAs $(9,6 \mathrm{~g} / \mathrm{d})$ with placebo, on top of the usual treatment. Interestingly, participants in the $\omega 3$ PUFAs group had significant differences in HRSD (Hamilton Rating Scale for Depression) score from the fourth week after treatment (and this difference kept growing up to week 8) - though it was a preliminary trial and small sample.

Tanskanen et al. $[46,47]$ in research on a random sample, found that frequent fish consumption might be coupled with a reduced risk of suicidal ideation. In the Huan et al. study [48] there was nearly eightfold difference in the number of suicide attempts between the lowest and highest red blood cells EPA level quartiles.

Very interesting results on $\omega 3$ PUFAs effects on mood, cognitive and physiological function have been reported by researchers from the University of Siena [49]. The study aimed to examine the effects of $\omega 3$ supplementation on healthy volunteers performing a series of attention tests (tests involving different types of attention were used). The tests were accompanied by neurophysiological recordings (electroencephalogram «EEG» and electromyography «EMG») to evaluate the possible modification of neuroelectrical parameters. In each test the participants' mood was diagnosed (involving The Profile of Mood States «POMS») and the reaction time was recorded. Subjects were tested at the beginning of the experiment and after thirty five days. Blood samples were taken on day 1 and day 35 to analyze specific parameters: AA/EPA ratio, cholesterol, triglycerides, High-density lipoprotein (HDL), Low-density lipoprotein (LDL) and glycaemia. Over a period of 35 days they were supplemented with $\omega 3$ PUFAs. A control group was supplemented with placebo (olive oil). After 35-day supplementation, blood analyses showed that the AA/EPA ratio was strongly reduced by $\omega 3$ treatment. Supplementation with $\omega 3$ PUFAs was associated with clear variations in mood. The POMS 
analysis showed an increase in vigour and decrease in such mood states as: anger, anxiety, fatigue, depression and confusion. The reaction time in attention tests decreased after $\omega 3$. An EEG frequency distribution showed a shift towards low frequencies in all recordings after $\omega 3$ supplementation. In particular, after $\omega 3$ the percentage of the beta- 2 band decreased significantly in all tests and in the relaxation period. Its reduction was accompanied by a concomitant increase of the theta and alpha bands. Though it was a relatively small sample, the results strongly suggest that $\omega 3$ PUFA supplementation has a beneficial influence on general psychological state, including mood and cognitive function, nonspecific for depressive disorders. Data supplied by Fontani et al. reinforce the hypothesis of the direct action of $\omega 3$ fatty acids on the central nervous system. The authors assume that the importance of these results is strengthened by the fact that they occur within subjects in good health and leading a physically active life in whom 03 PUFAs improved an already good condition of well-being.

Omega-3 PUFA supplementation is reported to be beneficial in psychological distress [50].

Based on the evidence from epidemiological data, casecontrol studies of phospholipid PUFA levels in human tissues, and antidepressant effect in clinical trials, it can be concluded that $\omega 3$ PUFAs could help to decipher the unsolved enigma of depression and connect the body and mind. The deficit of $\omega 3$ PUFAs has been reported to be associated with neurological, autoimmune, cardiovascular, cerebrovascular and metabolic diseases, cancers, and psychological conditions and diseases. Animals fed with high ARA diet or treated with PGE2 were observed to show symptoms of low activity, anorexia, change in sleep pattern and attention, which are similar to somatic symptoms of depression in humans. The deficit of EPA and DHA in depression may be linked with cognitive dysfunction, mood disturbance, medical co-morbidity and somatic symptoms in depression. The role of $\omega 3$ PUFAs in immunity and mood function supports the promising psycho-neuro-immunological hypothesis of depression and provides an excellent example of body and mind interface [11].

It has not been precisely determined how $\omega 3$ PUFAs affect psychological function. There are several possible mechanisms by which EPA and DHA could improve mood in affective disorders. EPA and DHA are intrinsic to the molecular structure of the phospholipids of cell membranes. The fatty acids are crucial to their role in modulating the functioning of proteins in the membrane. PUFAs lend fluidity to cell membranes and have specific functional interactions with membrane enzymes, receptors and other proteins. EPA and DHA can inhibit protein kinase C signal transduction enzyme complex, block calcium influx into the cell through the L-type calcium channel, similar to the calcium channel blockers verapamil or nimodipine [31]. Omega-3 fatty acids are often employed in conjunction with conventional medicine. That is because some psychiatric patients with depression or persistent anxiety are dissatisfied with the apparent ineffectiveness of traditional treatments and seek a more holistic approach with fewer side effects. The role of $\omega 3$ PUFAs as an adjunct to antipsychotics and melatonin as a treatment or prophylactic agent for side effects remains ambiguous, requiring further trials with sound methodology [51].

In order to compile and compare data from different trials, Appleton et al. [52,53] conducted a study which aimed to systematically review several published randomized controlled trials investigating the effects of $\omega 3$ PUFAs on depressed mood.

Eight medical and health databases were thoroughly searched for all years on record up to June 2006 for trials that exposed participants to $\omega 3$ PUFAs or fish, measured depressed mood, and were conducted on human participants with inclusion of a reference group.

Twelve randomized controlled trials were identified and included in the meta-analysis. The participants either had diagnosis of various different clinical conditions or were healthy volunteers. The pooled standardized difference in mean outcome (fixed-effect model) was 0.13 SDs $(95 \% \mathrm{CI}$ : $0.01 ; 0.25)$ in those receiving $\omega 3$ PUFAs compared with placebo, with strong evidence of heterogeneity. A sensitivity analysis that excluded one large trial increased the effect size but did not reduce heterogeneity. Meta-regression provided some evidence that the effect was stronger in trials involving populations with major depression - the difference in the effect size was 0.73 (95\% CI: $0.05 ; 1.41 ; \mathrm{P}=0.04)$, but there was still significant heterogeneity when trials that involved populations with major depression were pooled separately.

Appleton and associates' research indicates that trial evidence which examines the effects of $\omega 3$ PUFAs on depressed mood is limited and difficult to summarize and evaluate, due to its considerable heterogeneity. Most trials were small in scale, short in duration, and used different combinations of different doses of $\omega 3$ in varied groups of subjects. The evidence analyzed provides some support for the use of $\omega 3$ PUFAs in improving depressed mood. Larger trials with adequate precision to detect clinically important benefits are still required.

Indeed, the effects of $\omega 3$ PUFAs on depressed mood and cognitive function remain unclear. In fact, there is a number of studies showing the lack of therapeutically important effects of $\omega 3$ PUFA supplementation on mood and psychological states.

Silvers et al. [54] conducted a placebo-controlled trial of fish oil in the treatment of depression. They found no evidence that fish oil improved mood when compared to placebo oil. A study by Hakkarainen $e t$ al. [55] examined a total of 29.133 men aging from 50 to 69 years in a populationbased trial in Finland and did not find associations between the dietary intake of 13 PUFAs or fish consumption and depressed mood, major depressive episodes or suicide. However, we must take under consideration that mean fish consumption is much higher in Finland then in many other European countries (i.e. Poland). British researchers [56] conducted a large double-blind randomised controlled trial to evaluate the effects of EPA+DHA supplementation $(1,5 \mathrm{~g} / \mathrm{d})$ on mood and cognitive function in mildly to moderately depressed individuals (190 participants completed 12 weeks intervention). Compliance, confirmed by plasma fatty acid concentrations, was good, but there was no evidence of a difference between supplemented and placebo groups in the 
depression subscale of DASS (Depression, Anxiety and Stress Scales) at 12 weeks (adjusted difference in mean: -1,0; 95\% CI; P=0,27). Other measures of mood, mental health and cognitive function, including Beck Depression Inventory (BDI) score and attention bias toward threat words, were similarly little affected by the intervention. Substantially increasing EPA+DHA intake for 3 months was found not to have beneficial or harmful effects on mood in mild to moderate depression

Table 2 presents the findings of available articles. It includes: authors, year of publication, type and size of research group, daily dose applied in research and obtained results [see 57-84]. The table shows different effects of $\omega 3$ on depressed mood.

Table 2. Chronological list of clinical trials investigating effects of omega-3 PUFA on depressed mood and other affective manifestations.

\section{NUTRIENTS AND COGNITIVE FUNCTION}

It seems $\omega 3$ PUFA intake may be associated with human cognitive function. However, the majority of studies conducted in this field have considered only pathological situations. Many investigations have ascertained that dietary intake of fish and $\omega 3$ PUFAs is associated with lower risk of cognitive impairment, Alzheimer disease, dementia and stroke [i.e. 32, 84-89]. Relatively few studies have examined the beneficial role of $\omega 3$ PUFAs on cognitive performance in healthy adults.

Assessments of the cognitive benefits in adults are limited because of a lack of information on the characteristics and diets of food supplement users and the fact that those who seem healthier are also more likely to watch their diet, use supplements, etc. The relationship between better retention of cognitive function in later life and diet might be explained by better lifelong cognitive function informing health choices in old age.

The studies in this field also use observational design and relatively few studies of the cognitive benefits of proper diet and food supplement use have adjusted the results for the possible role of mental ability in earlier life, mainly because this information is usually not available. There is strong suggestion that $\omega 3$ PUFA intake affects cognitive performance in adults [90].

Whalley et al. [91, 92] conducted an observational study of 350 mentally efficient subjects born in 1936 whose mental ability was tested in 1947 and who were followed up to in 2000/01, at which point cognition, supplement use, diet, and risk factors for vascular disease were assessed. This investigation showed that use of food supplements in late adulthood can influence cognitive performance. This influence does not depend on differences in cognitive ability present in childhood. Specific cognitive advantages at the age of 64 were found in users of food supplements, including fish oils compared with non-users. Cognitive advantages were found in the digit symbol subtest, which is highly sensitive to cognitive aging and Alzheimer disease. The blood samples of fish oil users and nonusers were examined; there were significant correlations between childhood IQ and erythrocyte $\omega 3$ PUFAs in 2000/01. This means that higher childhood IQ is probably related to higher $\omega 3$ PUFA / fish oil consumption in later adulthood. IQ at age $64 \mathrm{y}$ was significantly correlated in the total sample with erythrocyte $\omega 3$ PUFA content and with the ratios of DHA/AA and $\omega 6 / \omega 3$ PUFAs. Whalley et al. conclude that greater dietary fish oil consumption is related to higher cognitive function in late adulthood.

The results coincide with those of the investigation conducted by Nurk et al. [93]. A large cross-sectional study with 2031 healthy subjects over 70 y showed a similar relation between intake of different amounts of seafood and cognitive performance.

It was found that fish eaters have significantly better results on all six cognitive tests used (Kendrick Object Learning Test «KOLT», Trial Making Test Part A «TMT-A», Digit Symbol Test Modified «m-DST», Block Design «m$\mathrm{BD} »$, Modified version of the Mini-Mental State Examination «m-MMSE», Abridged version of the Controlled Oral Word Association «S-task») than non-consumers. People who declared mean daily intake of fish and fish products $\geq 10 \mathrm{~g} / \mathrm{d}$ had significantly better mean results in cognitive tests and a lower prevalence of poor cognitive performance than did those whose intake was $<10 \mathrm{~g} / \mathrm{d}$. The associations between total intake of seafood and cognition strongly depended on dose and the type of fish. The maximum effect was reported at an intake of about $75 \mathrm{~g} / \mathrm{d}$ and with fatty fish (a richest source of $\omega 3$ PUFAs).

The association between plasma $\omega 3$ PUFA proportions and cognitive performance in older adults was also shown in another longitudinal study [93]. Researchers found that higher plasma proportions of $\omega 3$ PUFA predicted significantly less decline in such cognitive domains as sensory motor speed and complex speed over three years than did lower proportions of $\omega 3$ PUFAs.

It has not been determined whether cognitive decline is pathological or the result of a normal aging process. Nonetheless, current scientific data indicates that fish / $\omega 3$ PUFA consumption may be associated with slower decline; which seems a valuable piece of information.

The results above ought to be considered with a dose of scepticism. As in all observational studies, the direction of associations between cognitive scores in late life, selfreported supplement use, and blood $\omega 3$ PUFAs, remains uncertain. In example, participants with higher mental ability may be better informed about healthy nutritional habits, and eat a diet rich in $\omega 3$, vitamins etc.

Randomized controlled trials offer much greater degree of control of experimental variables, such as composition and quantity of taken PUFAs, than do observational studies. Such design allows us to avoid many of the potential problems that often render more difficult the interpretation of observational study.

The effects of $\omega 3$ supplementation on some cognitive and physiological parameters in healthy subjects (22 to $51 \mathrm{y}$ ) have been examined in controlled trials conducted by Fontani et al. [49]. Different types of attention have been measured in a 35-day $\omega 3$ PUFA supplementation group vs placebo group. Omega-3 PUFA supplementation has been found to be associated with a positive effect on reactivity, 
Table 2. Studies Showing Role of Omega-3 Fatty Acids in Depression

\begin{tabular}{|c|c|c|c|c|c|c|c|c|}
\hline \multirow[b]{2}{*}{ No. } & \multirow[b]{2}{*}{ Study } & \multirow[b]{2}{*}{ Year } & \multirow[b]{2}{*}{ Group } & \multirow{2}{*}{$\begin{array}{c}\text { No. of Subjects, Total: } \\
\text { Treatment/Placebo }\end{array}$} & \multicolumn{2}{|c|}{ Intervention } & \multirow{2}{*}{$\begin{array}{l}\text { Outcome } \\
\text { Measures }\end{array}$} & \multirow{2}{*}{$\begin{array}{r}\text { Statistical } \\
\text { Significant } \\
\text { Difference }\end{array}$} \\
\hline & & & & & Daily Close & Duration (d) & & \\
\hline 1 & Behan et al. & 1990 & chronic fatigue syndrome & $63: 39 / 24$ & $\begin{array}{l}0,10,14 \mathrm{~g} \text { EPA } \\
000,09 \mathrm{~g} \text { DHA }\end{array}$ & 90 & Likert scale & Yes \\
\hline 2 & Warren et al. & 1999 & chronic fatigue syndrome & $50: 24 / 26$ & $\begin{array}{c}100,14 \mathrm{~g} \text { EPA } \\
0,09 \mathrm{~g} \mathrm{DHA}\end{array}$ & 90 & BDI & No \\
\hline 3 & Stoll et al. & 1999 & bipolar disorder & $30: 14 / 16$ & $\begin{array}{l}6,2 \mathrm{~g} \text { EPA } \\
3,4 \mathrm{~g} \text { DHA }\end{array}$ & 112 & HDRS & Yes \\
\hline 4 & Fenton et al. & 2001 & schizophrenia & $87: 43 / 44$ & $3,0 \mathrm{~g}$ E-EPA & 112 & MADRS & No \\
\hline 5 & Peet et al. & 2001 & schizophrenia & 45 & $\begin{array}{l}2 \mathrm{~g} \mathrm{EPA} \\
2 \mathrm{~g} \mathrm{DHA}\end{array}$ & 84 & PANSS & Yes \\
\hline 6 & Voight et al. & 2001 & (children) [9y] ADHD & 54 & $0,345 \mathrm{~g}$ EPA & 112 & $\begin{array}{c}\text { CBC- } \\
\text { Attention }\end{array}$ & No \\
\hline 7 & Keck et al. & 2002 & bipolar disorder & $116: 59 / 57$ & $6,0 \mathrm{~g}$ E-EPA & 120 & IDS-c & No \\
\hline 8 & Nemets et al. & 2002 & $\begin{array}{c}\text { unipolar depressive } \\
\text { disorder }\end{array}$ & $20: 10 / 10$ & 2,0g E-EPA & 28 & HDRS & Yes \\
\hline 9 & $\begin{array}{l}\text { Peet and } \\
\text { Horrobin }\end{array}$ & 2002 & major depression & $\begin{array}{c}70: 17 \rightarrow 1 \mathrm{~g} / \mathrm{d} \\
18 \rightarrow 2 \mathrm{~g} / \mathrm{d} \\
17 \rightarrow 4 \mathrm{~g} / \mathrm{d}\end{array}$ & $1 ; 2 ; 4 \mathrm{~g}$ EPA & 84 & $\begin{array}{c}\text { HDRS } \\
\text { MADRS } \\
\text { BDI }\end{array}$ & Yes \\
\hline 10 & Emsley et al. & 2002 & schizophrenia & 40 & 3,0g E-EPA & 84 & $\begin{array}{c}\text { PANSS } \\
\text { ESRS }\end{array}$ & Yes \\
\hline 11 & $\begin{array}{l}\text { Peet and } \\
\text { Horrobin }\end{array}$ & 2002 & schizophrenia & 115 & $\begin{array}{c}0,01 \mathrm{~g} ; 0,02 \mathrm{~g} \\
0,04 \mathrm{~g} \mathrm{EPA}\end{array}$ & 84 & - & No \\
\hline 12 & $\begin{array}{l}\text { Richardson } \\
\text { and Puri }\end{array}$ & 2002 & $\begin{array}{l}\text { (children) }[10 \mathrm{y}] \\
\text { learning difficulties }\end{array}$ & 29 & $\begin{array}{l}0,186 \mathrm{~g} \text { EPA } \\
0,48 \mathrm{~g} \text { DHA }\end{array}$ & 84 & $\begin{array}{c}\text { (1) No of } \\
\text { DSM ADHD } \\
\text { symptoms } \\
\text { present } \\
\text { (2) CPRS }\end{array}$ & $\begin{array}{l}\text { (1) No } \\
\text { (2) Yes }\end{array}$ \\
\hline 13 & Llorente et al. & 2003 & Postpartum depression & $99: 44 / 45$ & ok. $0,2 \mathrm{~g}$ DHA & 120 & BDI & No \\
\hline 14 & Marangell et al. & 2003 & major depression & $36: 18 / 18$ & $2,0 \mathrm{~g}$ DHA & 42 & $\begin{array}{l}\text { MADRS } \\
\text { HDRS }\end{array}$ & No \\
\hline 15 & Su et al. & 2003 & major depression & 28: $14 / 14$ & $\begin{array}{l}4,4 \mathrm{~g} \text { EPA } \\
2,2 \mathrm{~g} \mathrm{DHA}\end{array}$ & 56 & HDRS & Yes \\
\hline 16 & $\begin{array}{l}\text { Zanarini and } \\
\text { Frankenburg }\end{array}$ & 2003 & $\begin{array}{l}\text { borderline personality } \\
\text { disorder }\end{array}$ & $30: 20 / 10$ & 1,0g E-EPA & 56 & MADRS & Yes \\
\hline 17 & Post et al. & 2003 & bipolar disorder & 121 & 6g EPA & 112 & - & No \\
\hline 18 & Fux et al. & 2004 & ocd & 11 & 2,0g E-EPA & 42 & HDRS & No \\
\hline 19 & Hirashima et al. & 2004 & bipolar disorder & $21: 12 / 9$ & $\begin{array}{c}5,0-5,2 \mathrm{~g} \text { EPA } \\
3,0-3,4 \text { DHA } \\
\text { or } \\
1,3 \mathrm{~g} \mathrm{EPA} \\
0,7 \mathrm{~g} \mathrm{DHA}\end{array}$ & 28 & HDRS & Yes \\
\hline 20 & Hirayama et al. & 2004 & (children) [9y] ADHD & 40 & $\begin{array}{c}0,1 \mathrm{~g} \mathrm{EPA}+ \\
0,512 \mathrm{~g} \mathrm{DHA}\end{array}$ & 56 & $\begin{array}{c}\text { No of DSM } \\
\text { ADHD } \\
\text { symptoms } \\
\text { present }\end{array}$ & No \\
\hline
\end{tabular}


Table 2. contd....

\begin{tabular}{|c|c|c|c|c|c|c|c|c|}
\hline \multirow[b]{2}{*}{ No. } & \multirow[b]{2}{*}{ Study } & \multirow[b]{2}{*}{ Year } & \multirow[b]{2}{*}{ Group } & \multirow{2}{*}{$\begin{array}{c}\text { No. of Subjects, Total: } \\
\text { Treatment/Placebo }\end{array}$} & \multicolumn{2}{|c|}{ Intervention } & \multirow{2}{*}{$\begin{array}{l}\text { Outcome } \\
\text { Measures }\end{array}$} & \multirow{2}{*}{$\begin{array}{l}\text { Statistical } \\
\text { Significant } \\
\text { Difference }\end{array}$} \\
\hline & & & & & Daily Close & Duration (d) & & \\
\hline 21 & Silvers et al. & 2005 & major depression & $77: 40 / 37$ & $\begin{array}{l}0,6 \mathrm{~g} \text { EPA } \\
2,4 \mathrm{~g} \text { DHA }\end{array}$ & 84 & $\begin{array}{l}\text { HDRS-SF } \\
\text { BDI }\end{array}$ & No \\
\hline 22 & Fontani et al. & 2005 & healthy subjects & 49: $33 / 16$ & $\begin{array}{c}1,6 \mathrm{~g} \mathrm{EPA} \\
0,8 \mathrm{~g} \text { DHA } \\
0,4 \mathrm{~g} \text { other } \mathrm{n}-3 \text { PUFAs }\end{array}$ & 35 & POMS & Yes \\
\hline 23 & Osher et al. & 2005 & bipolar disorder & 12 & 1,5-2g EPA & up to 168 & HDRS & Yes \\
\hline 24 & Freeman et al. & 2005 & Postpartum depression & $\begin{array}{c}16: \\
6 \rightarrow 0,5 \mathrm{~g} \text { EPA+DHA } \\
3 \rightarrow 1,4 \mathrm{~g} \text { EPA+DHA } \\
7 \rightarrow 2,8 \mathrm{~g} \text { EPA+DHA }\end{array}$ & $\begin{array}{c}0,5 \mathrm{~g} \text { EPA+DHA } \\
1,4 \mathrm{~g} \text { EPA+DHA } \\
2,8 \mathrm{~g} \text { EPA+DHA } \\
\text { ratio EPA:DHA } \rightarrow 1,5: 1\end{array}$ & 56 & $\begin{array}{l}\text { EPDS } \\
\text { CGI } \\
\text { HRSD }\end{array}$ & $\begin{array}{l}\text { Yes (lack of } \\
\text { placebo- } \\
\text { control } \\
\text { group) }\end{array}$ \\
\hline 25 & Frangou et al. & 2006 & bipolar disorder & $\begin{array}{l}75: 24 \rightarrow 1 \mathrm{~g} / \mathrm{d} \\
25 \rightarrow 2 \mathrm{~g} / \mathrm{d} \\
26 \rightarrow \text { placebo }\end{array}$ & $1 ; 2 \mathrm{~g} / \mathrm{d}$ E-EPA & 84 & $\begin{array}{l}\text { HSRD } \\
\text { CGI }\end{array}$ & Yes for $1 \mathrm{~g} / \mathrm{d}$ \\
\hline 26 & Nemets et al. & 2006 & $\begin{array}{l}\text { (children) }[6-12 \mathrm{y}] \\
\text { major depression } \\
\text { ADHD }\end{array}$ & 28: $13 / 15$ & $\begin{array}{l}\text { Ok. } 0,4 \mathrm{~g} \text { EPA } \\
\text { Ok. } 0,2 \mathrm{~g} \text { DHA }\end{array}$ & 112 & $\begin{array}{l}\text { CDRS } \\
\text { CDI } \\
\text { CGI }\end{array}$ & Yes \\
\hline 27 & Hallahan et al. & 2007 & $\begin{array}{l}\text { patients with } \\
\text { recurrent } \\
\text { self-harm }\end{array}$ & $49: 22 / 27$ & $\begin{array}{l}1,2 \mathrm{~g} \mathrm{EPA}+ \\
0,9 \mathrm{~g} \text { DHA }\end{array}$ & 84 & $\begin{array}{c}\text { BDI } \\
\text { HDRS } \\
\text { OAS-M } \\
\text { IMT/DMT } \\
\text { PSS }\end{array}$ & Yes \\
\hline 28 & Amminger et al. & 2007 & $\begin{array}{c}\text { (children) }[10 \mathrm{y}] \\
\text { autism }\end{array}$ & 13 & $\begin{array}{l}0,84 \mathrm{~g} \text { EPA } \\
0,7 \mathrm{~g} \text { DHA }\end{array}$ & 42 & $\mathrm{ABC}$ & No \\
\hline 29 & Rogers et al. & 2008 & $\begin{array}{l}\text { mild to moderate } \\
\text { depressive disorder }\end{array}$ & 190: $96 / 94$ & $\begin{array}{l}0,63 \mathrm{~g} \text { EPA } \\
0,85 \mathrm{~g} \text { DHA }\end{array}$ & 84 & $\begin{array}{c}\text { DASS } \\
\text { BDI } \\
\text { GHQ } \\
\text { STAI }\end{array}$ & No \\
\hline 30 & $\begin{array}{l}\text { Van de Rest } \\
\text { et al. }\end{array}$ & 2008 & $\begin{array}{l}\text { older subjects ( } \geq 65 \mathrm{y}) \\
\text { independently living }\end{array}$ & 302 & $\begin{array}{c}1,8 \mathrm{~g} \mathrm{EPA}+\mathrm{DHA} \\
\text { or } \\
0,4 \mathrm{gEPA}+\mathrm{DHA}\end{array}$ & 182 & $\begin{array}{l}\text { CES-D } \\
\text { MADRS } \\
\text { GDS-15 } \\
\text { HADS-A }\end{array}$ & No \\
\hline 31 & $\begin{array}{c}\text { Buydens- } \\
\text { Branchey et al. }\end{array}$ & 2008 & Substance abusers & $22: 11 / 11$ & $\begin{array}{c}2,25 \mathrm{~g} \text { EPA }+0,5 \mathrm{~g} \mathrm{DHA}+ \\
0,25 \text { other PUFAs }\end{array}$ & 84 & POMS & Yes \\
\hline \multirow[t]{2}{*}{32} & \multirow[t]{2}{*}{ Lucas et al. } & \multirow[t]{2}{*}{2009} & $\begin{array}{l}\text { middle aged women } \\
\text { with moderate-to severe } \\
\text { psychological distress } \\
\text { (with and without MDE } \\
\text { diagnosis) }\end{array}$ & 120: $59 / 61$ & $\begin{array}{l}1,05 \mathrm{~g} \text { E-EPA } \\
0,15 \mathrm{~g} \text { E-DHA }\end{array}$ & 56 & $\begin{array}{c}\text { PGWB } \\
\text { HSCL-D-20 } \\
\text { HAM-D-21 }\end{array}$ & No \\
\hline & & & $\begin{array}{l}\text { middle aged women } \\
\text { with moderate-to severe } \\
\text { psychological distress } \\
\text { (without MDE diagnosis) }\end{array}$ & $91: 46 / 45$ & $\begin{array}{l}1,05 \mathrm{~g} \text { E-EPA } \\
0,15 \mathrm{~g} \text { E-DHA }\end{array}$ & 56 & $\begin{array}{c}\text { PGWB } \\
\text { HSCL-D-20 } \\
\text { HAM-D-21 }\end{array}$ & Yes \\
\hline
\end{tabular}

i.e. reduction of reaction time in the Go/No-Go and Sustained Attention tests. The latency of EMG activation was concomitantly reduced in the same test plus Choice. EEG frequency shift to the alpha and theta band were recorded in all the tests after $\omega 3$ PUFA supplementation. These results indicate a beneficial influence of $\omega 3$ PUFAs on cognitive functions (attention) in healthy humans. It is possible that they improve an already healthy level of cognitive function. The authors definitely ascribe changes in the reaction time and psychological parameters to the action of $\omega 3$ on the central nervous system. These results are in line with the above mentioned effects of $\omega 3$ PUFAs in pathological circumstances. 


\section{CONCLUSIONS}

In this work we have outlined the evidence that particular nutrients influence the structure, the biochemistry and the functioning of the central nervous system. Fatty acids of the $\omega 3$ family probably have a beneficial effect on both affective and cognitive function, probably more in long term prevention and in acute treatment. Although some lines of investigation showed negative results, the data available shed new light on potential nutrition issues relative to the modern diet, and open the field to further studies.

The data concerning $\omega 3$ PUFAs effects on affective and cognitive function remain rather limited and often ambiguous in interpretation. However, the available evidence forces us to lend thorough consideration to the issue of dietary management in treating depression and other mental disorders. These data provide topics for interpretation and further research, which seems crucial. Indeed, the role of $\omega 3$ PUFAs in affecting immunity and affective function may support the promising psycho-neuro-immunological hypothesis of depression and appears to reveal the interface of body and mind (holistic approach). It seems that polyunsaturated fatty acids may become useful for prophylactic and/or therapeutic treatment of mood disorders and even for cognitive decline in senescence. What is more, it has been suggested that $\omega 3$ PUFAs might play a similarly beneficial role also in healthy humans' mental function. Data indicate that high $\omega 3$ PUFA dietary consumption might stabilize one's mood by reducing negative emotional states such as anxiety, anger and depression. The nutrients are considered to be factors that induce rather short term effects, so that they should be administrated on a continuing basis to maintain long term efficacy.

More studies, however, are needed, particularly with double-blind placebo controlled trials. Although functional effects on the CNS of dietary variations in essential fatty acids seem widely accepted as a fact, the underlying biochemical mechanisms are poorly understood and are not currently an area of intensive study. As noted, a great deal of studies on correlates between psychological outcomes and dietary compounds mainly involve pathological situations. Data concerning nutrients and affective/cognitive function of healthy people remain insufficient. One might have reservations about the dietary-intake-control methods typically used - such as dietary questionnaires, $\omega 3$ PUFA blood level (which does not say much about past nutrition habits), and about fish consumption recommendations and/or supplement capsules intake in intervention trials. Moreover, the most controlled trials published have been rather small and the duration rarely exceeded 90 days. It seems essential to provide randomised trials with functional food enriched in precisely determined specific nutrients composition.

There are still further unsolved issues related to the role of $\omega 3$ fatty acids. First of all, there is not enough data on potential undesirable effects of long term $\omega 3$ supplementation. Why does the $1-2 \mathrm{~g} / \mathrm{d} \omega 3$ PUFA dose seem more effective than higher amounts? What is the optimal ratio between EPA and DHA? And finally, what period of regular supplementation is necessary in order to reach maximal therapeutic response?
We believe that the significance of $\omega 3$ PUFAs in diet is undeniable, as they have been a natural part of our diet since the onset of the brain across all living species, humans in particular. In fact, it is only in the last two centuries that consumption of $\omega 3$ PUFAs has decreased in the western world, mainly because of food processing and commercial issues. Many authors see this dietary change as one of the main sources of continual increase in chronic degenerative diseases in modern societies. It appears that $\omega 3$ polyunsaturated fatty acids may become useful in both prophylaxis and treatment of many human conditions including mental disorders. It seems vital to gradually fill the gaps in common knowledge in this area.

\section{REFERENCES}

[1] Salem NJr, Litman B, Kim HY, Gawrish K. Mechanisms of action of docosahexaenoic acid in the nervous system. Lipids 2001; 36: 945-59.

[2] Piomelli D. Eicosanoids in synaptic transmission. Crit Rev Neurbiol 1994; 8: 65-83.

[3] Haag M. Essential fatty acids and the brain. Can J Psychiatry 2003; 48: 195-203

[4] Jones CR, Arrai T, Rapoport SI. Evidence for the involvement docosahexanoic acid in chollinergic stimulated signal transduction at the synapse. Neurochem Res 1997; 22: 663-70.

[5] Singh R. Study of Nutrition, Anxiety, Stress and Behaviour in Relation to Cardiovascular Risk Factors in the Elderly Urban Population of Moradabad, India, Thesis for $\mathrm{PhD}$, Department of Psychology, Gokuldas Girls College, Moradabad, Rohilkhand University, Bareilly, 1998.

[6] Singh RB, Niaz MA, Ghosh S, et al. Dietary intake, and plasma levels of antioxidant vitamins in health and disease, case study. J Nutr Environ Med 1995; 5: 235-42.

[7] Anderson GH. Diet, neurotransmitters and brain function. Br Med Bull 1981; 37: 95-100.

[8] Wurtman RJ. Behavioural effects of nutrients. Lancet 1983; 1: 1145-7.

[9] Maes M, Mihaylova I, Kubera M, Bosmans E. Why fish oils may not always be adequate treatments for depression or other inflammatory illnesses: docosahexaenoic acid, an omega-3 polyunsaturated fatty acid, induces a Th-1-like immune response. Neuro Endocrinol Lett 2007; 28: 875-80.

[10] Colin A, Reggers J, Castronovo V, Ansseau M. Lipids, depression and suicide. Encephale 2003; 29(1): 49-58.

[11] Su KP. Mind-body interface: the role of n-3 fatty acids in psychoneuroimmunology, somatic presentation, and medical illness comorbidity of depression. Asia Pac J Clin Nutr 2008; 17 (Suppl 1): 151-7.

[12] Sontrop J, Campbell MK. Omega-3 polyunsaturated fatty acids and depression: a review of the evidence and a methodological critique. Prev Med 2006; 42(1): 4-13.

[13] Lin PY, Su KP. A meta-analytic review of double-blind, placebocontrolled trials of antidepressant efficacy of omega-3 fatty acids. J Clin Psychiatry 2007; 68(7): 1056-61.

[14] Kronenberg G, Harms C, Sobol RW, et al. Folate deficiency induces neurodegeneration and brain dysfunction in mice lacking uracil DNA glycosylase. J Neurosci 2008; 28(28): 7219-30.

[15] Joseph JA, Shukitt-Hale B, Lau FC. Fruit polyphenols and their effects on neuronal signaling and behavior in senescence. Ann N Y Acad Sci 2007; 1100: 470-85.

[16] Delion S, Cahlon S, Guilloteau G, Hérault J Besnard JC, Durand G. Chronic dietary alpha-linolenic acid deficiency alters dopaminergic and serotinergic neurotransmission in rats. J Nutr 1994; 124: 26676.

[17] Delion S, Cahlon S, Guilloteau G, Besnard JC, Durand G. Alphalinolenic acid deficiency alters age-related changes of dopaminergic and serotoninergic neurotransmission in the rat frontal cortex. $\mathbf{J}$ Neurochem 1996; 66: 1582-91.

[18] Hibbeln JR, Salem N. Dietary polyunsaturated fatty acids and depression: when cholesterol does not satisfy. Am J Clin Nutr 1995; 62: 1-9. 
[19] Yehuda S, Rabinovitz S. Crasso RL, Mostofsky DI. The role of polyunsaturated fatty acids in restoring the aging of neuronal membrane. Neurobiol Aging 2002; 23: 843-53.

[20] Martin RE, Bazan NG. Changing fatty acid content of growth cone lipids prior to synaptogenesis. J Neurochem 1992; 59: 318-25.

[21] Neuringer M, Reisbick S, Janowsky J. The role of omega-3 fatty acids in visual and cognitive development: Current evidence and methods of assessments. J Pediatr 1994; 125: S39-47.

[22] Willats P. Long chain polyunsaturated fatty acids improve cognitive development. J Fam Health Care 2002; 12(S6): 5.

[23] Bakker EC, Ghys AJ, Kester AD, Vles JS, Dubas JS, Blanco CE. Long-chain polyunsaturated fatty acids at birth and cognitive function ant 7 y of age. Eur J Clin Nutr 2003; 57: 89-95.

[24] Helland IB, Smith L, Saarem K, Saugstad OD, Drevon CA. Maternal supplementation with very-long-chain Omega-3 fatty acids during pregnancy and lactation augments children's IQ at four years of age. Pediatrics 2003; 111: 39-44.

[25] McCann JC, Ames BN. Is docosahexaenoic acid, an n-3 long-chain polyunsaturated fatty acid, required for development of normal brain function? An overview of evidence from cognitive and behavioral tests in humans and animals. Am J Clin Nutr 2005; 82(2): 281-95.

[26] Yehuda S, Rabinovitz S, Mostofsky DI. Essential fatty acids are mediators of brain biochemistry and cognitive functions. J Neurosci Res 1999; 56: 565-70.

[27] Yehuda S. Omega-6/Omega-3 ratio and brain related functions. World Rev Nutr Diet 2003; 92: 37-56.

[28] La Guardia M, Giammanco S, Di Majo D, Tabacchi G, Tripoli E, Giammanco M. Omega 3 fatty acids: biological activity and effects on human health. Panminerva Med 2005; 47(4): 245-57.

[29] Innis SM. Dietary (n-3) fatty acids and brain development. J Nutr 2007; 137: 855-9.

[30] Mazza M, Pomponi M, Janiri L, Bria P, Mazza S. Omega-3 fatty acids and antioxidants in neurological and psychiatric diseases: An overview. Prog Neuropsychopharmacol Biol Psychiatry 2007; 31:12-26.

[31] Fabrigoule C, Rouch I, Taberly A, et al. Cognitive procces in preclinical phase of dementia. Brain 1998; 121: 135-41.

[32] Freeman MP. Omega-3 fatty acids in psychiatry : a review. Ann Clin Psychiatry 2000; 12: 159-65.

[33] Hakkarainen R, Partonen T, Haukka J, Albanes D, Lonnqvist J. Is low dietary intake of omega-3 fatty acid associated with depression? Am J Psychiatry 2004; 161: 567-9.

[34] Stoll AL, SeverusWE, Freeman MP, et al. Omega-3 fatty acids in bipolar disorder - a preliminary double-blind, placebo-controlled trial. Arch Gen Psychiatry 1999; 56: 407-12.

[35] Silvers KM, Scott KM. Fish consumption and self physical and mental health status. Public Health Nutr 2002; 5: 427-31.

[36] Hibbeln JR. Fish consumption and major depression. Lancet 1998; 351: 1213 .

[37] Timonen M, Horrobin DF, Jokelainen J, Laitinen JM, Herva AM, Rasanen P. Fish consumption and depression: the Northern Finland 1966 birth cohort study. J Affect Disord 2004; 82: 447-52.

[38] Noaghiul S, Hibbeln JR. Cross-national comparisons of seafood consumption and rates of bipolar disorders. Am J Psychiatry 2003; 160: 2222-7.

[39] Cott J, Hibbeln JR. Lack of seasonal mood change in Icelanders. Am J Psychiatry 2001; 158: 328.

[40] Parker G, Gibson NA, Brotchie H, Heruc G, Rees A, HadziPavlovic D. Omega-3 fatty acids and mood disorders. Am J Psychitry 2006; 163: 969-78.

[41] Klerman GL, Weissman MM. Increasing rates of depression. JAMA1989; 261: 2229-35.

[42] Edwards R, Peet M, Shay J, Horrobin D. Depletion of docosahexaenoic acid in red blood cell membranes of depressive patients. Biochem Soc Trans 1998; 26: S142.

[43] Peet M, Murphy B, Shay J, Horrobin D. Depletion of omega-3 fatty acid levels in red blood cell membranes of depressive patients. Biol Psychiatry 1998; 43: 315-9.

[44] Tiemeier H, Van Tuijl HR, Hoffman A, Kiliaan AJ, Breteler MM. Plasma fatty acid composition and depression are associated in the elderly: the Rotterdam study. Am J Clin Nutr 2003; 78(1): 406.

[45] Nemets B, Stahl Z, Belmaker RH. Addition of omega-3 fatty acid to maintenance medication treatment for recurrent unipolar depressive disorder. Am J Psychiatry 2002; 159: 477-9.
[46] Tanskanen A, Hibbeln JR, Tuomilehto J. Fish consumption and depressive symptoms in general population in Finland. Psychiatr Serv 2001; 52: 529-31.

[47] Tanskanen A, Hibbeln JR, Hintikka J. Fish consumption, depression, and suicidality in a general population. Arch Gen Psychiatry 2003; 58: 512-3.

[48] Huan M, Hamazaki K, Sun Y, et al. Suicide attempt and n-3 fatty acid levels in red blood cells: a case control study in China. Biol Psychiatry 2004; 56:490-6.

[49] Fontani G, Corradeshi F, Felici A, Alfatti F, Migliorini S, Lodi L. Cognitive and physiological effects of Omega-3 polyunsaturated fatty acid supplementation in healthy subjects. Eur J Clin Invest 2005; 35(11): 691-9.

[50] Hamazaki T, Sawazaki S, Itomura M. The effect of docosahexaenoic acid on aggression in young adults. A placebo-controlled double-blind study. J Clin Invest 1996; 97: 1129-33.

[51] Werneke U, Turner T, Priebe S. Complementary medicines in psychiatry: review of effectiveness and safety. $\mathrm{Br} \mathrm{J}$ Psychiatry 2006; 188: 109-201.

[52] Appleton KM, Hayward RC, Gunnell D, et al. Effects of n-3 long-chain polyunsaturated fatty acids on depressed mood: systematic review of published trials. Am J Clin Nutr 2007; 85(6): 1665-6.

[53] Appleton KM, Gunnell D, Peters TJ, Ness AR, Kessler D, Rogers PJ. No clear evidence of an association between plasma concentrations of n-3 long-chain polyunsaturated fatty acids and depressed mood in a non-clinical population. Prostaglandins Leukot Essent Fatty Acids 2008; 78(6): 337-42.

[54] Silvers KM, Woolley CC, Hamilton FC, Watts PM, Watson RA. Randomised double-blind placebo-controlled trial of fish oil in the treatment of depression. Prostaglandins Leukot Essent Fatty Acids 2005; 72: 211- 8 .

[55] Hakkarainen R, Partonen T, Haukka J, Virtamo J, Albanes D, Lonnqvist $\mathrm{J}$. Is low dietary intake of omega-3 fatty acids associated with depression? Am J Psychiatry 2004; 161: 567-9.

[56] Rogers PJ, Appleton KM, Kessler D, et al. No effect of n-3 longchain polyunsaturated fatty acid (EPA and DHA) supplementation on depressed mood and cognitive function: a randomised controlled trial. Br J Nutr 2008; 99: 421-431.

[57] Behan PO, Behan WMH, Horrobin D. Effect of high doses of essential fatty acids on the postviral fatigue syndrome. Acta Neurol Scand 1990; 82: 209 -16.

[58] Warren G, McKendrick M, Peet M. The role of essential fatty acids in chronic fatigue syndrome. Acta Neurol Scand 1999; 99: 112-6.

[59] Fenton WS, Dickerson F, Boronow J, Hibbeln JR, Knable M. A placebo-controlled trial of omega-3 fatty acid (ethyl eicosapentaenoic acid) supplementation for residual symptoms and cognitive impairment in schizophrenia. Am J Psychiatry 2001; 158: 2071-4.

[60] Peet M, Brind J, Ramchand CN, Shah S, Vankar GK. Two doubleblind placebo-controlled pilot studies of eicosapenaenoic acid in the treatment of schizophrenia. Schizophr Res 2001; 49: 243-51.

[61] Voigt G, Llorente AM, Jensen CL, Fraley JK, Barretta MC, Heird WC. A randomized double-blind, placebo-controlled trial of docosahexaenoic acid supplementation in children with attentiondeficit/hyperactivity disorder. J Pediatr 2001; 139: 189-96.

[62] Keck PE, Freeman MP, McElroy SL, et al. A double-blind placebo controlled trial of eicosapentaenoic acid in rapid cycling bipolar disorder. Bipolar Disord 2002; 4(suppl): 26-7.

[63] Peet MB, Horrobin DF. A dose-ranging study of the effects of ethyleicosapentaenoate in patients with ongoing depression despite apparently adequate treatment with standard drugs. Arch Gen Psychiatry 2003; 59: 913-9.

[64] Emsley R, Myburgh C, Oosthuizen P, Van Rensburg SJ. Randomized, placebo-controlled study of ethyleicosapentaenoic acid as supplemental treatment in schizophrenia. Am J Psychiatry 2002; $159 ; 1596-8$.

[65] Peet M, Horrobin DF, E-E Multicentre Study Group. A doseranging exploratory study of the effects of ethyl-eicosapentaenoate in patients with persistent schizophrenic symptoms. J Psychiatr Res 2002; 36; 7-18.

[66] Richardson AJ, Puri BK. A randomised double-blind, placebocontrolled study of the effects of supplementation with highly unsaturated fatty acids on ADHD-related symptoms in children with specific learning difficulties. Prog Neuropsychopharmacol Biol Psychiatry 2002; 26: 233-9. 
[67] Llorente AM, Jensen CL, Voigt RG, Fraley JK, Berretta MC, Heird WC. Effect of maternal docosahexaenoic acid supplementation on postpartum depression and information processing. Am J Obstet Gynecol 2003; 188: 1348 -53.

[68] Marangell LB, Martinez JM, Zboyan HA, Kertz B, Seung Kim HF, Puryear LJ. A double-blind, placebo-controlled study of the omega3 fatty acid docosahexaenoic acid in the treatment of major depression. Am J Psychiatry 2003; 160: 996-8.

[69] Su KP, Huang SY, Chiu CC, Shen WW. Omega-3 fatty acids in major depressive disorder - a preliminary double-blind placebocontrolled trial. Eur Neuropsychopharmacol 2003; 13: 267-71.

[70] Zanarini MC, Frankenburg MD. Omega-3 fatty acid treatment of women with borderline personality disorder: a double-blind, placebo-controlled pilot study. Am J Psychiatry 2003; 160: 167-9.

[71] Post RM, Leverich GS, Altshuler LL, et al. An overview of recent findings of the Stanley foundation bipolar network (part I). Bipolar Disord 2003; 5: 310-9.

[72] Fux M, Benjamin J, Nemets B. A placebo-controlled cross-over trial of adjunctive EPA in OCD. J Psychiatr Res 2004; 38: 323-5.

[73] Hirashima F, Parow AM, Stoll AL, et al. Omega-3 fatty acid treatment and $\mathrm{T} 2$ whole brain relaxation times in bipolar disorder. Am J Psychiatry 2004; 161:1922- 4.

[74] Hirayama S, Hamazaki T, Terasawa K. Effect of docohexaenoic acid-containing food administration on symptoms of attentiondeficit/hyperactivity disorder - a placebo-controlled double-blind study. Eur J Clin Nutr 2004; 58: 467-73.

[75] Fontani G, Corradeshi F, Felici A, et al. Blood profiles, body fat and mood state in healthy subjects on different diets suplemented with omega-3 polyunsaturated fatty acids. Eur J Clin Invest 2005; 35: 499-507.

[76] Osher Y, Bersudsky Y, Belmaker RH. Omega-3 Eicosapentaenoic Acid in Bipolar Depression: Report of Smal Open Label Study. J Clin Psychiatry 2005; 66: 726-9.

[77] Freeman MP, Hibbeln JR, Wisner KL, Brumbach BH, Watchman M, Gelenberg AJ. Randomized dose-ranging pilot trial of omega-3 fatty acids for postpartum depression. Acta Psychiatr Scand 2006; 113: 31-5

[78] Frangou S, Lewis M, McCrone P. Efficacy of ethyleicosapentaenoic acid in bipolar depression: randomised doubleblind placebo-controlled study. Br J Psychiatry 2006; 188: 46-50.

[79] Nemets H, Nemets B, Apter A, Bracha Z, Belmaker RH. Omega-3 treatment of children's depression: a controlled, double-blind pilot study. Am J Psychiatry 2006; 163: 1098-100.

[80] Hallahan B, Hibbeln JR, Davis JM, Garland MR. Omega-3 fatty acid supplementation in patients with recurrent self-harm: Single centre double-blind randomised controlled trial. Br J Psychiatry 2007; 190: 118-22.
[81] Amminger GP, Berger GE, Schafer MR, Klier C, Friedreich MH, Feucht M. Omega-3 fatty acids supplementation in children with autism: a double-blind randomized, placebo-controlled pilot study. Biol Psychiatry 2007; 61: 551-3

[82] Van de Rest O, Geleijnse JM, Kok FJ, et al. Effect of fish-oil supplementation on mental well-being in older subjects: a randomized double-blind, placebo-controlled trial. Am J Clin Nutr 2008; 88: 706-13.

[83] Buydens-Branchey L, Branchey M, Hibbeln JR. Associations between increases in plasma n-3 polyunsaturated fatty acids following supplementation and decreases in anger and anxiety. Prog Neuropsychopharmacol Biol Psychiatry 2008; 32: 568-75.

[84] Lucas M, Asselin G, Merette C, Poulin MJ, Dodin S. Ethyleicosapentaenoic acid for treatment of psychological distress and depressive symptoms in middle-aged women: a double-blind, placebo-controlled, randomized clinical trial. Am J Clin Nutr 2009; 89: 641-51

[85] Issa AM, Mojica WA, Morton SC, et al. The efficacy of omega-3 fatty acids on cognitive function in aging and dementia: a systematic review. Dement Geriatr Cogn Disord 2006; 21: 88-96.

[86] Morris MC, Evans DA, Tangney CC, Bienias JL, Wilson RS. Fish consumption and cognitive decline with age in a large community study. Arch Neurol 2005; 62(12): 1849-53.

[87] Heude B, Ducimetiere P, Berr C. Cognitive decline and fatty acid composition of erythrocyte membranes - The EVA Study. Am J Clin Nutr 2003; 77: 803-8

[88] Kalmijn S, Launer LJ, Ott A, Witteman JC, Hofman A, Breteler MM. Dietary fat intake and the risk of incident dementia in the Rotterdam study. Ann Neurol 1997; 42: 776-82.

[89] Moriguchi T, Salem N. Rocovery of branin docosahexaenoate leads to recovery spatial performance. J Neurochem 2003; 87: 297309.

[90] Whalley LJ, Fox HC, Wahle KW, Starr JM, Deary IJ. Cognitive aging, childhood intelligence, and the use of food supplements: possible involvement of n-3 fatty acids. Am J Clin Nutr 2004; 80: $1650-7$

[91] Whalley LJ, Deary IJ, Starr JM, et al. N-3 fatty acid erythrocyte membrane content, APOE $\varepsilon 4$, and cognitive variation: an observational follow-up study in late adulthood. Am J Clin Nutr 2008; 87: 449-54.

[92] Nurk E, Drevon CA, Refsum H, et al. Cognitive performance among the elderly and dietary fish intake: the Hordaland Health Study. Am J Clin Nutr 2007; 86: 1470-8.

[93] Dullemeijer C, Durga J, Brouwer IA, et al. n-3 fatty acid proportions in plasma and cognitive performance in older adults. Am J Clin Nutr 2007; 86: 1479-85. 